\title{
Parameters selection of extended-range electric vehicle supplied with alternative fuel
}

\author{
Artur Kopczyński ${ }^{1,{ }^{*}}$, Pawet Krawczyk ${ }^{1}$, and Jakub Lasocki ${ }^{2}$ \\ ${ }^{1}$ Warsaw University of Technology, Department of Multisource Propulsion Systems, Narbutta 84, \\ 02-524 Warsaw, Poland \\ ${ }^{2}$ Warsaw University of Technology, Department of Combustion Engines, Narbutta 84, 02-524 \\ Warsaw, Poland
}

\begin{abstract}
In this paper modelling of extended-range electric vehicle powertrain. The model consists of sub-models of the investigated vehicle with its resistance forces, traction electric motor, range extender supplied with alternative fuel, and Li-Ion battery. Working point parameters of the range extender engine were defined to achieve low liquefied petroleum gas consumption. The model allowed to study possible parameters of vehicle range extender and battery size. The results show the higher influence of range extender power than battery energy capacity on the vehicle range. The defined range extender and battery parameters allow to significantly extend the vehicle range with low fuel consumption. This research provided ground for the further investigation of range extender control strategies.
\end{abstract}

\section{Introduction}

Due to the pollutants emission in large urban agglomerations, especially in city centres, limitation of conventional vehicle traffic is becoming more and more implemented in the world. For example, in Paris, the traffic of vehicles registered before 1997 was completely banned from July $1^{\text {st }}, 2016$ on weekdays between 8 and 20 o'clock due to the smog [1]. As an alternative to combustion vehicles, zero-emission vehicles are nowadays proposed, for example, these with electric drive. However, it should be noted that current vehicles that are only electrically powered are characterized by a relatively small driving range. Although this small range seems to be enough to move around the city on a daily basis, it is definitely insufficient to move between distant cities. Therefore, it is necessary to look for new solutions that allow improving the parameters of a pure-electric vehicle. One of such ideas may be Extended-Range Electric Vehicle (EREV) powered by alternative fuel.

The search for solutions to increase driving range of electric vehicles has attracted growing attention of automotive industry in the last decades, involving scientists and researchers from academic and commercial research institutions. Main issues addressed by the literature published in recent years include optimal EREV sizing as well as the influence of battery capacity, driving pattern and energy management strategy on energy efficiency, pollutant emissions and cost. It should be noted, however, that the variety of assumptions

* Corresponding author: artur.kopczynski@,simr.pw.edu.pl 
adopted in the research makes it impossible to indicate globally optimal EREV parameters, based solely on a literature review. In other words, the right size of the drivetrain components depends strongly on vehicle class, its annual mileage, production costs, user expectations and other parameters.

The most popular EREVs available on the market today include BMW i3 and Opel Ampera. Although both are passenger cars, they represent different market segments (B and $\mathrm{C}$, respectively) and have different technical characteristics (BMW/Opel): electric motor power of $125 / 111 \mathrm{~kW}$, ICE power of $25.4 / 63.0 \mathrm{~kW}$, fuel tank capacity of $9 / 35 \mathrm{dm}^{3}$, lithiumion battery capacity and weight of $18.8 / 16.0 \mathrm{kWh}$ and $230 / 198 \mathrm{~kg}$, electric-only range of $131 / 83 \mathrm{~km}$, total range of $250 / 580 \mathrm{~km}$, and curb weight of $1390 / 1715 \mathrm{~kg}$ [2]. An overview of EREVs parameters developed by other automotive companies was provided in paper [3].

Many scientific works were dedicated to the problem of right sizing of EREV drivetrain components, resulting in various solutions. A method based on the analyses of vehicle user profiles, which are retrieved from surveys carried out in European countries, was presented in publication [4]. According to these statistics, an average small EREV should have the following specifications: electric motor power of $47 \mathrm{~kW}$, range extender (RE) power of $19 \mathrm{~kW}$, battery capacity of $9 \mathrm{kWh}$ and vehicle curb weight of $1258 \mathrm{~kg}$, while compact EREV $-87 \mathrm{~kW}, 20 \mathrm{~kW}, 19 \mathrm{kWh}$ and $1751 \mathrm{~kg}$, respectively [5].

Another approach for the choice of drivetrain characteristics represents the advanced genetic algorithm combined with a quasi-optimal energy management strategy. The effectiveness of this method was demonstrated in the study [6], where light-duty commercial EREV was designed and then analysed over the Worldwide harmonized Light vehicles Test Cycle (WLTC) by means of a simulation model. For a $2000 \mathrm{~kg}$ vehicle, the authors selected ICE with a power of $46 \mathrm{~kW}$, electric motor with a power of $70 \mathrm{~kW}$ and a battery with a capacity of $11.8 \mathrm{kWh}$ providing an electric-only range of $52 \mathrm{~km}$.

One of the most comprehensive investigations addressing the issue of battery size of EREVs focused on a heterogeneity across drivers (e.g. average speed, annual mileage, trip distribution) [7]. The impact of different driving patterns on the optimal battery setup was examined from the perspective of total cost of vehicle ownership. The object of an analysis was medium size passenger EREV having a curb weight of $1580 \mathrm{~kg}$ and powered by $100 \mathrm{~kW}$ electric motor coupled with $50 \mathrm{~kW}$ ICE. Simulation results revealed that for the annual mileage of $15000 \mathrm{~km}$ and $30000 \mathrm{~km}$, a suitable battery has a capacity of $6 \mathrm{kWh}$ and $13 \mathrm{kWh}$, respectively, which corresponds to $24 \mathrm{~km}$ and $51 \mathrm{~km}$ of electric-only range.

The recent emergence of EREVs is a way to the development of dedicated ICEs that can be used as an additional power source [8]. The obvious choice is conventional four-stroke reciprocating piston engine characterized by good reliability, mature technology as well as low cost of production and maintenance [9]. However, increased applications of nontraditional concepts such as Wankel engine [10], five-stroke piston engine [11] or micro gas turbine [12] are observed. The use of unconventional fuels is very rarely proposed. For example, in the FUEREX project [13], the concept of range extenders capable of using renewable biofuels as well as regular fossil fuels was developed. According to some researchers [14], current ICE-based REs will gradually be replaced by hydrogen fuel cell stack systems.

\section{Extended-range electric vehicle}

Due to the similarity of the structure of EREV to the structure of hybrid drives in a serial configuration, they are often classified in the same category. The difference lies mainly in the capacity of energy storage (greater than in hybrid drives, but smaller than in electric drives) and in the method of controlling the power flow in the system [15]. The use of a small combustion engine allows a significant extension of the EREV driving range in relation to 
pure electric cars and at the same time the size of the electric energy accumulator is reduced and the current load is lowered, which significantly affects the lifetime of the electrochemical battery. Depending on the mode of operation of the vehicle powertrain, it is possible to drive only with the use of an electric motor - driving mode with "zero emission" of pollution and reduced noise and vibrations transmitted from the vehicle to the environment. This is an unquestionable advantage, as in a growing number of large urban agglomerations (e.g. London) the city centres are closed for conventional vehicles powered by internal combustion engines. Another advantage of this solution is the support of the electric motor by RE in conditions of high power demand (acceleration, driving at maximum speed, driving uphill). Moreover, EREV vehicles are equipped with a regenerative braking system, which reduces energy consumption [16].

According to the scheme presented in Figure 1, the vehicle is driven by an electric motor (EM) controlled by a motor controller (MC) powered by an electrochemical battery (Bat). The braking/accelerating torque is transferred via a reducer with a fixed ratio (FG) connected to the differential gear $(\mathrm{X})$ and drive shafts. The vehicle range extension system (RE) consists of an internal combustion engine (ICE) and an electric generator $(\mathrm{G})$ that simultaneously can operate as a starter motor for ICE. The fuel tank (FT) is connected to the internal combustion engine (ICE). The central control unit (CCU) defines the operation of the electric drive system (EV) and the range extender (RE). The central control unit (CCU) decides about switching RE on and off based on the information on the battery Stage of Charge (SoC) and the parameters given by the driver and related to the current driving conditions. Mechanical and electrical connections are presented with continuous $(-)$ and dashed $(---)$ lines, respectively. The drive system shown in Figure 1 can work in the following operating modes: 1. Driving in pure electric mode, 2. Driving in hybrid mode: a) with energy usage from the battery and from RE, b) with energy usage only from RE. 3. Regenerative braking - charging the battery.

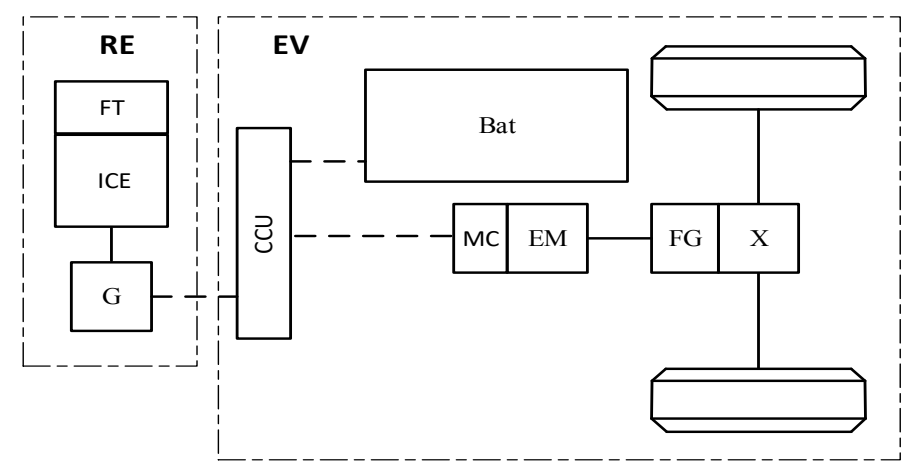

$$
\begin{aligned}
& \text { Bat }- \text { Battery } \\
& \mathrm{MC}- \text { Motor } \\
& \text { Controller } \\
& \mathrm{EM}- \text { Electric Motor } \\
& \mathrm{ICE}- \text { Internal } \\
& \text { Combustion } \\
& \text { Engine } \\
& \mathrm{FT}- \text { Fuel Tank } \\
& \mathrm{FG}- \text { Final Gear } \\
& \mathrm{X}- \text { Differential Gear } \\
& \mathrm{CCU}- \text { Central Control } \\
& \text { Unit } \\
& \text { mechanical } \text { conection } \\
& \text { electrical } \\
& \text { conection }
\end{aligned}
$$

Fig. 1. Powertrain configuration of the range-extended electric vehicle.

\section{ICE configuration}

To meet the requirements of a newly developed concept of city electric vehicle, RE should provide desired power output while simultaneously demonstrate maximum efficiency (minimum fuel consumption), minimum emission of pollutants and noise, low weight and size, low purchase and maintenance costs and adaptability to mass production. There are several different types of heat engines that meet some of the assumptions mentioned above, including four/two stroke, spark-/compression-ignition reciprocating piston engines, rotary piston engines, free piston engines, and gas turbine engines. However, each of them has certain deficiencies that need to be overcome. Under the conditions of physical and technical 
constraints, with limited economic possibilities, the optimal solution for the present project is shifted towards the four-stroke, reciprocating piston, spark-ignition ICE.

At the initial stage of this investigation, a variety of engine fuels for ICE were evaluated based on the results of scientific research and automotive market analysis. By assumption, the use of alternative fuels, both as a replacement or as a partial supplement to conventional gasoline and diesel oil, was favoured. The following criteria were applied for the evaluation of the fuels: availability, viability of the application in passenger cars, pollutant emissions and fuel consumption, compatibility with existing distribution and storage infrastructure, current technological status, timescale for production implementation (if applied). Finally, for the specific type of application and expected intensity of fuel consumption, Liquefied Petroleum Gas (LPG) was deemed to be the best choice.

LPG is widely used as an engine fuel, powering over 25 million vehicles worldwide [17]. It has a well-established infrastructure, is readily available in the adequate quantities and there are enough reserves to meet the demands of transportation for many decades in the future. LPG is relatively safe and less expensive than gasoline and diesel oil. Compared to conventional fuels, LPG-supplied engines emit lower or at least similar amounts of some toxic air pollutants and greenhouse gases [18].

There are two possible configurations of LPG supply system in vehicles: bi-fuel and dedicated; the former consist of two separate fuelling systems to use either LPG or gasoline while the latter run solely on LPG. In both cases, LPG is stored in a liquid state inside a tank under moderate pressure. LPG can be introduced to the engine in the vapour phase, mixed with air before in the intake manifold, or in liquid form through direct injection into the combustion chamber. In the present study, direct injection of liquid LPG was chosen for implementation in RE. This system allows better control of combustion process for improved efficiency and reduction of pollutant emissions [19].

Properly designed RE should be right sized in order to satisfy the performance requirements of a vehicle and, at the same time, make it economically competitive. In the preliminary analysis, the appropriate power output of a RE was rated at around $10 \mathrm{~kW}$. This value range is influenced by the maximum vehicle speed in an extended-range mode and the general drivetrain control strategy, which is discussed further in this paper. The capacity of the LPG fuel tank was set at the level of $10 \mathrm{dm}^{3}$ to meet the required range of the vehicle.

For simulation purposes, 4-cylinder, spark-ignition ICE with LPG direct injection was adopted from the study [19]. The structure of the drivetrain, in which ICE is not mechanically connected to the wheels of the vehicle, allows the engine to operate at maximum thermal efficiency for fuel consumption improvements. The specific operating point was selected based on the downscaled map of Brake Specific Fuel Consumption (BSFC) shown in Figure 2.

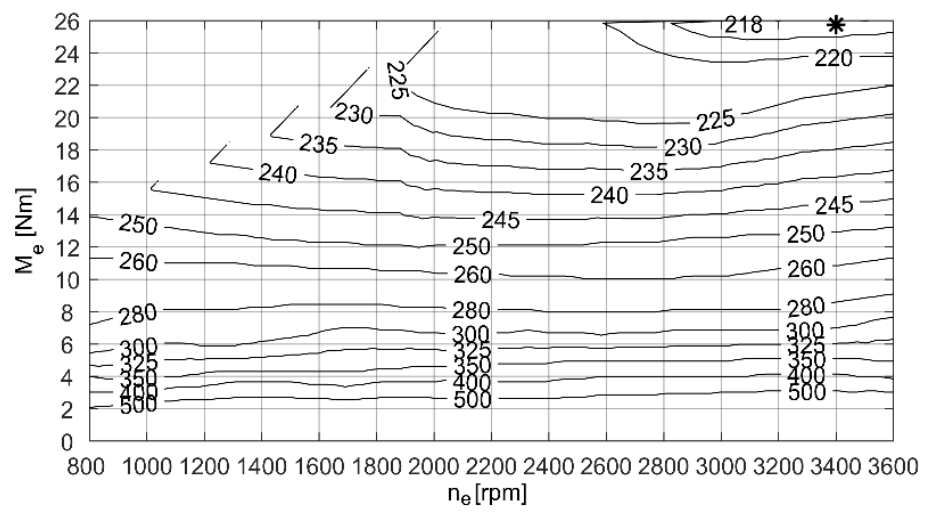

Fig. 2. RE engine BSFC downscaled map based on [19] with marked operating point. 


\section{Modelling and simulations}

\subsection{Powertrain model}

Model of the vehicle is based on equations which purpose is to capture power flow from the battery and RE, through vehicle traction motor and down to the traction wheels [20]. Main restrain is that the vehicle is driven in such manner that its speed follows the WLTC $3 \mathrm{~b}$ test cycle. Forces acting on the vehicle are tire friction force, air drag force and force of inertia of rotating drivetrain components. Equation 1 show sum of these forces, making total resistance force acting on the vehicle wheels. The friction force is constant and depends on vehicle mass $m$, gravitational acceleration $g$, and friction coefficient $f_{t}$. Frontal air drag force is a function of air density $\rho$, vehicle frontal area $A$, drag coefficient $c_{d}$ and momentary value of vehicle speed. Last three terms of the Equation 1 represent force of the inertia, dependent on vehicle acceleration $a(t)$. This force is associated with vehicle mass $\mathrm{m}$, wheels inertia $J_{w}$ and electric motor rotor inertia $J_{m}$. The number of rolling wheels is given by $n_{w}, r_{d}$ is the dynamic radius of tires, $\eta_{d}$ is drivetrain efficiency, and $i$ is a motor-wheels mechanical ratio.

$$
F_{r}(t)=m g f_{t}+0.5 \rho A c_{d} v(t)^{2}+m a(t)+n_{w} J_{w} a(t) / r_{d}^{2}+\eta_{d}^{\operatorname{sign}[\operatorname{Fr}(t)]} J_{m} i^{2} a(t) / r_{d}^{2}
$$

External torque acting on the electric motor shaft is given by Equation 2.

$$
M_{r}(t)=\left[m g f_{t} r_{d}+0.5 \rho A c_{d} v(t)^{2} r_{d}+m a(t)+n_{w} J_{w} a(t) / r_{d}\right] \eta_{d} \operatorname{sign}[F r(t)] / i
$$

The electric motor shaft is connected with wheels and here stiffness of this connection is omitted, therefore to calculate vehicle acceleration caused by motor electromagnetic torque $M_{r}$, it is possible to calculate motor acceleration $\varepsilon_{m}$ first (Equation 3). $M_{c}$ is a constant value of motor torque losses. Actual vehicle speed the can be calculated by equation 4, which complete iteration loop.

$$
\begin{gathered}
\varepsilon_{m}(t)=\left[M_{m}(t)-M_{c}-M_{r}(t)\right] / J_{m} \\
v(t)=\left[\int \varepsilon_{m}(t) d t\right] r_{d} / i
\end{gathered}
$$

Motor controller voltage is controlled in such way that allows obtaining required WLTC $3 \mathrm{~b}$ cycle speed $v_{c}(t)$ (Equation 5), although it is limited to a DC-link voltage value. Coefficients $k_{p}$ and $k_{i}$ are PI regulator constants.

$$
u_{m}(t)=k_{p}\left[v_{c}(t)-v(t)\right]+k_{i} \int\left[v_{c}(t)-v(t)\right] d t
$$

Motor model is given by Equations 6 and 7. Coefficients $c_{i}$ and $c_{u}$ are motor current constant and motor electromotive force constant respectively. Motor resistance is given by $R_{m}$ and motor inductance by $L_{m}$. Motor current $i_{m}(t)$ is limited to its rated value.

$$
\begin{gathered}
M_{m}(t)=c_{i} i_{m}(t) \\
\omega_{m}(t)=\left\{u_{m}(t)-R_{m} i_{m}(t)-L_{m}\left[d i_{m}(t) / d t\right]\right\} / c_{u}
\end{gathered}
$$

The motor is characterised also by its base speed and by its maximal speed. From speed equal zero to base speed $n_{b}$, the motor operates in constant torque region. From base speed to maximal speed $n_{m}$ motor operates in constant power region, in which motor constants are adjusted to simulate magnetic field weakening. In the second region, motor torque characteristic decays with speed increase. Motor power at DC-link is given by Equation 8, where $\eta_{m c}$ is the motor converter efficiency. 


$$
P_{m}(t)=u_{m}(t) i_{m}(t) / \eta_{m c} \operatorname{sign}[P m(t)]
$$

RE fuelled by LPG comprises from engine and generator with a converter. Engine model is given by brake specific fuel consumption map. Motor and converter are represented with constant efficiencies $\eta_{r m}$ and $\eta_{r c}$, because RE will be working in a specific point, not changing in time. RE will be characterised by its output power $P_{r e}$. Engine power $P_{e}$ is given by Equation 9. Although it is assumed that the RE is working with constant output power, RE power is a function of time because it can be turned on or turned off.

$$
P_{e}(t)=P_{r e}(t) /\left(\eta_{r m} \eta_{r c}\right)
$$

Lithium-ion battery power is the sum of motor power and RE power that flows through battery converter, characterised by its efficiency $\eta_{b c}$. RE relieves battery, therefore RE power is taken with "-." (Equation 10).

$$
P_{b}(t)=\left[P_{m}(t)+\left(-P_{r e}(t)\right)\right] / \eta_{b c} \operatorname{sign}[\operatorname{Pr}(t)]
$$

The battery state of charge (SOC) is calculated by comparing momentary battery charge, given by battery current $I_{b}$ integrated over time to nominal battery full charge $Q_{b n}$ (Equation 11). Battery efficiency is included via Peukert's coefficient $\beta$, which relates momentary battery current to nominal battery current $I_{b n}[21]$.

$$
\operatorname{SOC}(t)=\operatorname{SOC}_{0^{-}}\left(1 / Q_{b n}\right) \int I_{b}(t)\left(I_{b}(t) / I_{b n}\right)^{(\beta-1) \operatorname{sign}[I b(t)]} d t
$$

Battery current is calculated using equivalent circuit equation of battery voltage, with an electromotive force of single battery cell $e_{b c}(S O C)$ and internal resistance of single battery cell $R_{b c}(S O C)$ (Equation 12). These parameters can be given in a form of polynomial functions as presented in [22]. The battery comprises of a number of cells, where $n_{b s}$ is number of series connections, and $n_{b p}$ is a number of parallel connections.

$$
U_{b}\left(S O C, I_{b}\right)=n_{b s}\left\{e_{b c}(S O C)-R_{b c}(S O C)\left[I_{b}(t) / n_{b p}\right]\right\}
$$

To connect battery current with battery power load and complete current calculation iteration loop, Equation 12 must be solved in conjunction with Equation 13.

$$
I_{b}(\mathrm{t})=P_{b}(t) / U_{b}\left(S O C, I_{b}\right)
$$

\subsection{Simulations}

The model was implemented into Matlab-Simulink software environment. For given input data sets main results were battery state of charge, a final value of RE fuel consumption, and vehicle range. Simulation runs were not limited by specified time of every simulation, but rather by minimal SOC value. When this preselected value was reached, the simulation stopped. Solver was set to ode $23 \mathrm{t}$, with the maximal variable time step of $0.01 \mathrm{~s}$. Simulink block diagram is presented in Figure 3. Simulated vehicle followed WLTC $3 b$ with no discrepancies between the momentary cycle speed and the vehicle speed.

Simulated vehicle is based in large amount on the parameters of $1^{\text {st }}$ generation Nissan Leaf electric vehicle (Table 1). The vehicle has two passengers on board. The RE mass and the battery mass vary across the simulated variants (Table 2), and it is accounted in the simulations. RE is enabled when requested vehicle speed exceeds $20 \mathrm{~km} / \mathrm{h}$ (or $35 \mathrm{~km} / \mathrm{h}$ for the largest power RE) to ensure that battery SOC drops during the cycle, providing extendedrange operation. It is assumed that all RE variants operate at the same BSFC value of 218 $\mathrm{g} / \mathrm{kWh}$. 


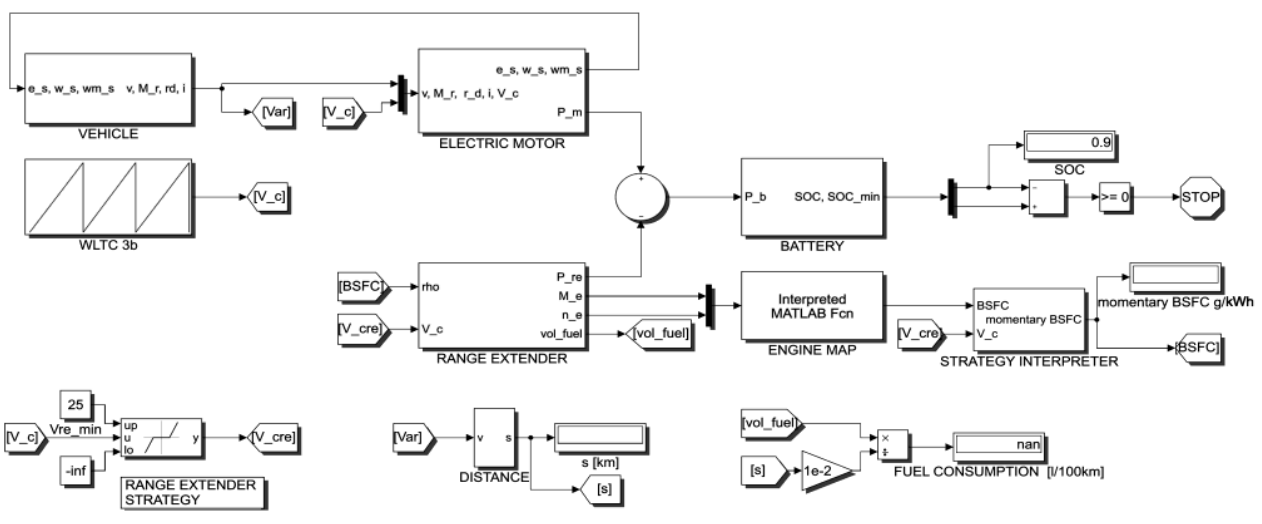

Fig. 3. Simulink block diagram of the EREV model.

Table 1. Main parameters of simulated EREV.

\begin{tabular}{|l|c|c|c|c|c|}
\hline Parameter & Mass $m^{*}$ & $\begin{array}{c}\text { Engine } \\
\text { power } P_{m}\end{array}$ & $\begin{array}{c}\text { RE specific } \\
\text { power }\end{array}$ & $\begin{array}{c}\text { Battery specific } \\
\text { energy }\end{array}$ & $\begin{array}{c}\text { Battery SOC } \\
\text { operation range }\end{array}$ \\
\hline Value & $1660 \mathrm{~kg}$ & $80 \mathrm{~kW}$ & $0.172 \mathrm{~kW} / \mathrm{kg}$ & $0.126 \mathrm{kWh} / \mathrm{kg}$ & $0.3-0.9$ \\
\hline
\end{tabular}

* for $24.15 \mathrm{kWh}$ battery and $8.6 \mathrm{~kW}$ range extender

Table 2. Simulated EREV variants.

\begin{tabular}{|l|c|c|c|c|c|c|c|c|c|}
\hline Variant & I.A. & I.B. & I.C. & I.D. & II.A. & II.B. & II.C. & III.A. & III.B. \\
\hline Battery energy $[\mathbf{k W h}]$ & 24.15 & 24.15 & 24.15 & 24.15 & 18.11 & 18.11 & 18.11 & 12.07 & 12.07 \\
\hline RE power $\boldsymbol{P}_{\text {re }}[\mathbf{k W}]$ & 10.75 & 8.6 & 6.45 & 4.3 & 10.75 & 8.6 & 6.45 & 10.75 & 8.6 \\
\hline
\end{tabular}

\section{Results}

Figure 4 shows the power split between RE, electric motor and battery. RE switched on at the speed exceeding $25 \mathrm{~km} / \mathrm{h}$. The power coming from RE decreased battery current load in conditions of high power demand.

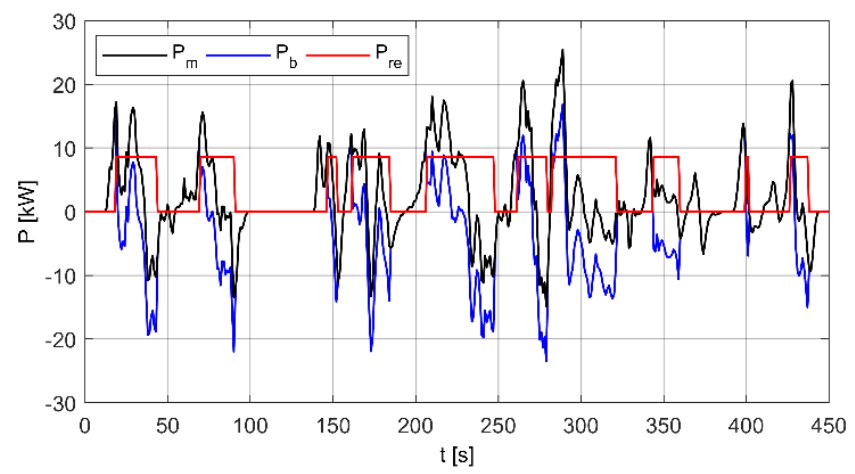

Fig. 4. Powers of the electric motor, battery, and RE at the timespan of $450 \mathrm{~s}$ of WLTC $3 \mathrm{~b}$. 
Figure 5 presents battery state of charge versus distance travelled. In Table 3 the results of simulated range and fuel consumption shows that minimal recommended RE power is 8.6 $\mathrm{kW}$ which gives the range over $340 \mathrm{~km}$, but at the same time, the battery energy capacity must be at least $18 \mathrm{kWh}$.

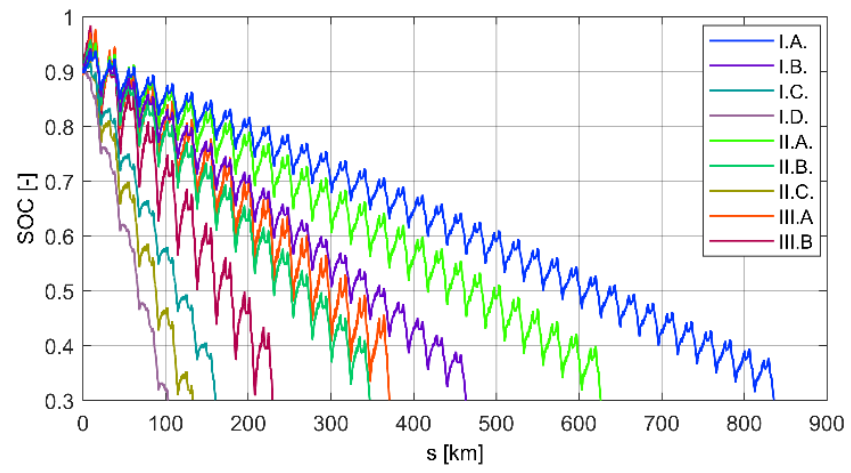

Fig. 5. Battery state of charge as a function of vehicle range for investigated EREV battery and RE combinations, in WLTC $3 b$.

Table 3. Comparison of simulation results.

\begin{tabular}{|c|c|c|c|c|}
\hline \multirow{2}{*}{\multicolumn{2}{|c|}{$\begin{array}{c}\text { Range }[\mathrm{km}] / \\
\text { fuel consumption }\left[\mathrm{dm}^{3} / 100 \mathrm{~km}\right]\end{array}$}} & \multicolumn{3}{|c|}{ Battery energy [kWh] } \\
\hline & & 24 & 18 & 12 \\
\hline \multirow{4}{*}{ RE power $P_{r e}[\mathrm{~kW}]$} & 10.75 & $835.8 / 5.9$ & $626.3 / 5.9$ & $370.6 / 5.9$ \\
\hline & 8.6 & $463.4 / 5.6$ & $347.0 / 5.6$ & $229.2 / 5.6$ \\
\hline & 6.45 & $160.4 / 4.3$ & $132.6 / 4.3$ & - \\
\hline & 4.3 & $103.1 / 2.9$ & - & - \\
\hline
\end{tabular}

\section{Conclusions}

In this study, four variants of LPG-fuelled range extender sizes and three variants of battery capacities were examined in EREV simulations. Obtained results showed significant differences in EREV range. The larger the battery size, the larger the vehicle range. Moreover, for higher powers of range extender, the range was considerably larger. This means that the influence of range extender size is more significant than battery size. Therefore there is a possibility for reduction of battery size through proper selection of range extender power and range extension at the same time. Range extender can work in the point of highest efficiency with the lowest fuel consumption. By implementation of an additional power source in a form of range extender, the battery load is reduced, hence better battery energy utilization can be achieved.

\section{References}

1. Paris bans cars registered before year 2000 in bid to combat city pollution, http://www.independent.co.uk/news/world/europe/paris-bans-vehicles-registerdbefore-2000-fight-city-air-pollution-france-emission-reducing-a7542921.html

2. R. A. Fernandez, F. B. Cilleruelo, I. V. Martinez, Int. J. Hydrog. Energy 41, 4808-4819 (2016)

3. J. Wolschendorf, K. Rzemien, D. Gian, SAE Int. J. Passeng. Cars - Electron. Electr. Syst. 3(2), 215-219 (2010) 
4. R. Derollepot, C. Weiss, Z. Kolli, T. Franke, R. Trigui, B. Chlond, J. Armoogum, J. Stark, R. Klementschitz, M. Baumann, S. Pélissier, Optimizing components size of an Extended Range Electric Vehicle according to the use specifications (Transport Research Arena, Paris, 2014)

5. M. Baumann, L. Brethauer, Environmental Impacts of Electric Vehicles with Range Extender on the Basis of European Vehicle Use Profiles (Karlsruher Institut für Technologie, Karlsruhe, 2014)

6. F. Millo, J. Zhao, L. Rolando, C. Cubito, R. Fuso, Comput. Aided Des. Appl. 12, 22-32 (2015)

7. M. Redelbach, E. D. Özdemir, H.E. Friedrich, Energy Policy 73, 158-168 (2014)

8. J. Ribau, C. Silva, F. P. Brito, J. Martins, Energy Conv. Manag. 58, 120-33 (2012)

9. J. Turner, D. Blake, J. Moore, P. Burke, R. Pearson, R. Patel, D. Blundell, R. Chandrashekar, L. Matteucci, P. Barker, C. Card, SAE Int. J. Engines 3(2), 318-51 (2010)

10. J. S. Salanki, P. A. Wallace, SAE Paper 960232 (1996)

11. A. Kéromnès, B. Delaporte, G. Schmitz, L. Le Moyne, Energy Conv. Manag. 82, 259-267 (2014)

12. R. Capata, E. Sciubba, Energy 58, 178-84 (2013)

13. FUEREX. The project co-funded by the 7 th Framework Programme of the EC. http://www.fuerex.eu

14. R. Á. Fernández, S. C. Caraballo, F. B. Cilleruelo, J. A. Lozano, Renew. Sust. Energ. Rev. 81, 655-668 (2018)

15. P. Krawczyk, A. Kopczyński, Proceedings of the Institute of Vehicles, 5, 31, (2016)

16. A. Kopczyński, Logistyka: czasopismo dla profesjonalistów, 3, 2269, (2015)

17. World LPG Association, Annual Report 2015, https://www.wlpga.org/wpcontent/uploads/2015/12/WLPGA-Annual-Report-2015-Light.pdf

18. C. Çinar, F. Sahin, Ö. Can, A. Uyumaz, Appl. Therm. Eng. 107, 1261-1268 (2016)

19. J. Kim, K. Kim, S. Oh, Fuel Process. Technol. 154, 219-226 (2016)

20. A. Kopczyński, P. Krawczyk, Proceedings of the Institute of Vehicles, 112 (3), 49, (2017).

21. M. Sekrecki, P. Krawczyk, A. Kopczyński, Logistyka: czasopismo dla profesjonalistów, 6, 9425, (2014)

22. P. Krawczyk, A. Kopczyński, Proceedings of the Institute of Vehicles, 112 (3), 59, (2017). 